\title{
AGEM400(HES), a Novel Erythropoietin Mimetic Peptide Conjugated to Hydroxyethyl Starch with Excellent In Vitro Efficacy
}

\author{
Alexandra Greindl, Claudia Kessler, Bettina Breuer, Udo Haberl, Andreas Rybka, \\ Marco Emgenbroich, Andy J.G. Pötgens* and Hans-Georg Frank
}

AplaGen GmbH, Arnold-Sommerfeld-Ring 2, D-52499 Baesweiler, Germany

\begin{abstract}
We developed and tested a compound called AGEM400(HES) that consists of a novel erythropoietin mimetic peptide (EMP) which is produced as a continuous $\mathrm{N}$ - to C-linked dimer and is conjugated to biodegradable hydroxyethyl starch (HES). In various in vitro assays, AGEM400(HES) demonstrated excellent efficacy, better than the peptide alone, and comparable to the efficacy of erythropoietin (EPO) and Aranesp (Darbepoietin alpha). The assays included survival assays on EPO-responsive cell lines (EC50 below $1 \mathrm{ng} / \mathrm{ml}$ peptide) and clonogenic assays on human bone marrow cells (EC50 1 to $10 \mathrm{ng} / \mathrm{ml}$ ). AGEM400(HES) caused phosphorylation of STAT5 and ERK signalling proteins in UT7/EPO cells in a similar fashion as EPO. AGEM400(HES) replaced EPO from its receptor and the in vitro activity of AGEM400 (HES) was inhibited by soluble EPO receptor. Antibodies generated in mice and rabbits against EPO did not recognize AGEM400(HES) peptide, and vice versa. A sensitive ELISA was able to detect AGEM400(HES) at low nanogram per $\mathrm{ml}$ concentrations which allows for bioanalytics of AGEM400(HES) serum levels in future in vivo studies. As a result, AGEM400(HES) is a promising drug candidate for anemias related to renal insufficiency and/or in oncological settings.
\end{abstract}

Keywords: Erythropoietin, erythropoietin mimetic peptide (EMP), erythropoietin receptor, hydroxyethyl starch (HES).

\section{INTRODUCTION}

Erythropoietin (EPO) is a cytokine synthesized by the kidney that regulates the synthesis of erythrocytes. As a drug, it is used for anemias that result from chronic kidney failure, cancer and anti-cancer treatment. There are currently many different variants of EPO as well as other erythropoiesis stimulating agents (ESAs) on the market. These include variants of EPO with an improved biological half-life, such as Darbepoietin alpha (Aranesp) and continuous erythropoietin receptor activator (CERA) in addition to EPO biosimilars [1-4]. An erythropoietin mimetic peptide (EMP-1), without any sequence homology with EPO, was introduced in 1996 as a chemically synthesized agent with the same biological activity as EPO [5]. An optimized dimeric EPO mimetic peptide (EMP) that is conjugated to polyethylene glycol (PEG) and called Hematide has finished clinical phase II $[1,6]$. A dimeric recombinant protein containing the EMP-1 sequence and the Fc portion of human IgG has also been tested in phase I studies under the name CNTO 528 [7].

The cellular mechanism of action of EPO mimetics appears to be identical to that of EPO in that they bind the EPO receptor and thereby cause phosphorylation of signalling proteins such as JAK2, STAT5 and others [8, 9]. Synthetic ESAs are, however, expected be cheaper to produce than recombinant EPO or variants thereof, mainly due to the complex purification procedures and various controls associated with recombinant production.

\footnotetext{
*Address correspondence to this author at the AplaGen GmbH, ArnoldSommerfeld-Ring 2, D-52499 Baesweiler, Germany; Tel: 49-2401-805580; Fax: 49-2401-805574; E-mail: apotgens@kpnmail.nl
}

Because the sequences of EMPs are different from the EPO protein sequence, antibodies that might develop against EMPs after long-term administration, are not likely to react with endogenous EPO. EPO-associated pure red cell aplasia (PRCA), which is the development of antibodies against recombinant EPO that neutralize the activity of endogenous $\mathrm{EPO}$, is a rare condition in patients being treated with EPO $[10,11]$. PRCA has not been observed and is not expected to occur after treatment with EMPs, meaning that in cases where PRCA already developed, EMPs may become the only effective treatment apart from blood transfusions [1].

The biological half-life of recombinant EPO was significantly increased in hyperglycosylated EPO variants such as Darpoietin alpha although this benefit is partly offset by decreased receptor binding affinities and in vitro efficacies [12]. PEGylation has also been used as a means of extending the biological half-life of many drugs, including that of an EPO variant (CERA) and of an EMP (Hematide) $[8,13]$. At the same time, PEGylation of recombinant cytokines has often led to decreased receptor binding affinities and decreased efficacies in vitro. This was not only the case in early attempts to increase the biological half-life of cytokines by randomly conjugating PEG to lysines $[14,15]$, but also in recent approaches with ESAs $[8,13]$.

Hematide, the EMP conjugated to PEG, was effective in healthy volunteers in increasing reticulocytes and hemoglobin, and these effects lasted for one month after a single application [6]. Even though PEGylated cytokines and other PEGylated drugs are used intensively in the clinic [16, 17], there is astonishingly little knowledge on the metabolism of larger PEG moieties, especially those with a molecular weight of $40 \mathrm{kD}$ or higher $[18,19]$. Although there is no evidence of short or medium term toxicity of Hematide [20, 21], 
the combination of a relatively small peptide being conjugated to a relatively large PEG with chronic use in patients with renal failure (who thus have a compromised ability to eliminate larger PEG molecules) is an unprecedented combination of properties of a PEGylated drug. Hematide clearance in rats with chronic renal injury was much slower than in healthy rats [8]. As a result, we thought the use of a biodegradable macromolecule instead of PEG would be preferable because it would allow even patients with impaired kidney function to degrade and eliminate the macromolecular carrier.

Here, we present AGEM400, a novel dimeric EMP conjugated to hydroxyethyl starch (HES) in a way that up to 5 peptide molecules are coupled to one HES molecule. The conjugate was called AGEM400(HES), and it is the prototype of a new generation of clinically applicable ESAs. HES is already clinically used as an active pharmaceutical ingredient (API) as a plasma volume substitute and plasma expander in high doses (in excess of $10 \mathrm{~g} /$ patient). The major fraction of HES is biodegradable by amylase, and its breakdown products are renally excreted [22]. Conjugation of AGEM400 to HES, primarily intended to improve half-life in vivo, also led to increased in vitro efficacy of the peptide. AGEM400(HES) is shown here to have an in vitro efficacy that is superior to that reported for Hematide [8] and competitive to that reported for CNTO 530 [9]. The mechanism of action of AGEM400(HES) appears to be similar to that of EPO and other EPO mimetics, while at the same time AGEM400(HES) appears to be immunologically distinct from EPO.

\section{MATERIALS AND METHODOLOGY}

\section{Sources of Erythropoietin}

Epoetin alfa from Ortho Biotech/Janssen-Cilag (Neuss, Germany, brand name: Erypo, stock solutions $16.8 \mu \mathrm{g} / \mathrm{ml}$ (2000 IE/ml) or $33.6 \mu \mathrm{g} / \mathrm{ml}(4000 \mathrm{IE} / \mathrm{ml})$ ) was used as a source of EPO in all experiments, except in some cases when Aranesp (Amgen, Munich, Germany, stock solution of 500 $\mu \mathrm{g} / \mathrm{ml})$ was also used.

\section{Peptides}

The sequence of our basic EMP, called BB68, differs at three positions from the published EMP-1 sequence [5, 23], in which both proline residues were replaced by lysines and a tryptophane was replaced by a 1-Naphthylalanine. A C-N linked dimer of BB68, with an addition of a C-terminal tBublocked cysteine residue, was synthesized continuously and called AGEM400. Internal disulfide bridges were closed between Cys(6)-Cys(15) and (in AGEM400) between Cys (26)-Cys(35), leading to the peptides depicted in Fig. (1). The structure of the AGEM400 dimer also differs from a published dimeric EMP [24] because those two monomeric units were linked between their $\mathrm{N}$-termini by PEG, while here a continuous dimer was produced with $\mathrm{C}-\mathrm{N}$ linked peptide bonds.

\section{Synthesis of Peptides}

Peptides BB68 and AGEM400 were synthesized at a scale of $0.25 \mathrm{mmol}$ by microwave assisted solid phase peptide synthesis in an automated Liberty (CEM) unit. The growing peptide chain was assembled on PAL ChemMatrix resin from Matrix Innovation. Deprotection was achieved by adding $10 \mathrm{ml}$ Piperidine (25\% in DMF) and irridation with $65 \mathrm{~W}$ for $3 \mathrm{~min}$. Coupling of the next amino acid was achieved using a five fold excess of reagents (amino acid, Pybop, DIEA) in $10 \mathrm{ml}$ DMF and irridation with $40 \mathrm{~W}$ for 5 min. All couplings were done by a double coupling procedure including capping with $\mathrm{Z}-2-\mathrm{Cl}-\mathrm{OSu}$ (40 equivalents) and irridation with $40 \mathrm{~W}$ for $2 \mathrm{~min}$. Acetylation of the peptide was achieved by introducing Ac-Gly-OH as last building block. After washing with DCM, the peptide was cleaved off by adding $40 \mathrm{ml}$ cleavage cocktail (94\% TFA, $1.0 \%$ TIS, $2.5 \% \mathrm{H}_{2} \mathrm{O}, 2.5 \%$ DODT) and incubating at RT for $3 \mathrm{~h}$. The peptide was then precipitated in cold ether, redisssolved in acetonitrile/water (2/1), and directly purified by LCMS using a Nebula (Gilson) purification system. The disulfide bond in BB68, and the first disulfide bond in AGEM400, were created by the use of AplaGen's cyclization reagent AGOX15 [25] using a simple protocol. This reagent has advantages compared with standard oxidation methods (oxygen, iodine) as no workup is needed to remove the reagent prior to purification and as it leads to higher yields. In a typical experiment, $10-20 \mathrm{mg}$ of the peptide was dissolved in $10 \mathrm{ml}$ AGOX15 (room atmosphere). After 18-24 h at RT this solution was directly purified by LCMS using a Nebula (Gilson) purification system. To create the second disulfide bond in AGEM400, the monocyclic peptide $(20 \mathrm{mg})$ was dissolved in $40 \mathrm{ml} 80 \%$ acetic acid. After addition of $0.512 \mathrm{ml} 0.1 \mathrm{M}$ $\mathrm{HCl}$ and $3.424 \mathrm{ml} 50 \mathrm{mM}$ iodine solution in acetic acid, the solution was stirred for $2.5 \mathrm{~h}$. Excess iodine was removed by adding ascorbic acid until the solution was colorless. The solution was then diluted with water to a total volume of 400 $\mathrm{ml}$ and added onto a C18-SPE-Column. The column was washed with $200 \mathrm{ml}$ water, and the peptide was eluted with $50 \mathrm{ml}$ acetonitrile/water (95/5). The crude peptide was directly purified by LCMS using a Nebula (Gilson) purification system. Because the 41-mer was purified 3 times by HPLC, a high purity of the final product could be achieved (above 90\%).

\section{Removal of the Remaining Cys(tBu)-Protection Before Conjugation to HES}

Purified bicyclic AGEM400 peptide was transferred into a teflon vessel and anisole was added. The vessel was cooled down with dry ice/acetone and HF was condensed into the vessel (anisol: $\mathrm{HF}=1: 10$ ). The deprotection was run at $0^{\circ} \mathrm{C}$ for $75 \mathrm{~min}$. HF was removed via recondensation followed by a nitrogen gas stream. The oily residue was precipitated with TBME and removed by centrifugation. The precipitant was then washed 4 times with TBME, taken up with $0.1 \%$ TFA in water and lyophilized over night. The crude peptide was purified by LCMS using a Nebula (Gilson) purification system.

\section{Conjugation to HES}

A hydroxyethyl starch HES200/0.5 was fractionated in order to obtain a size fraction with an $\mathrm{Mw}=130 \pm 20 \mathrm{kDa}$. A number of $30 \pm 3 \mu \mathrm{mol} / \mathrm{g}$ active groups were introduced in a three step modification process. For the conjugation of the deprotected AGEM400, $80 \mathrm{mg}(\mathrm{M}=4657.5 \mathrm{~g} / \mathrm{mol}, 1.2 \mathrm{eq}$, peptide/active thiol content $=70 \%$ ) of the peptide were dis- 


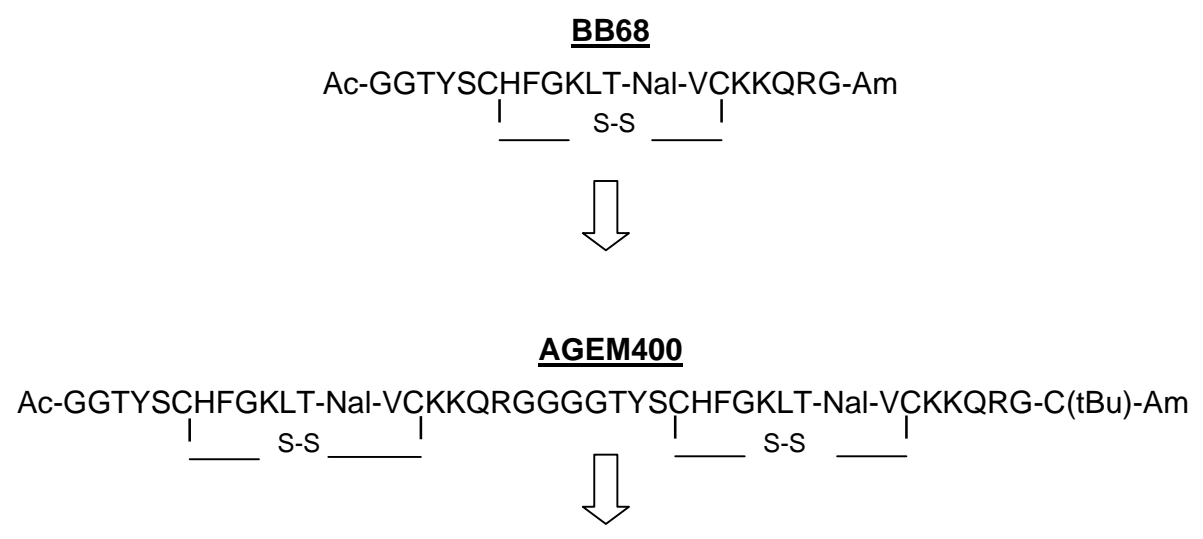

AG EM 400(HES)

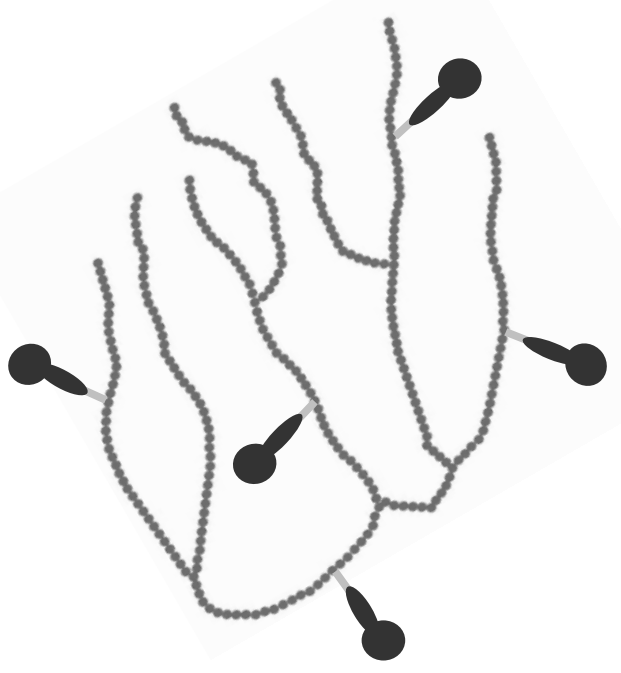

Fig. (1). Schematic of the EPO mimetic peptides used in this study: monomeric EMP BB68; dimeric AGEM400 with a C-terminal tBublocked cysteine; and AGEM400(HES), with on average 5 AGEM400 peptides per conjugate. Symbols: Ac: N-terminal acetylation; Nal: 1naphthylalanine; Am: C-terminal amidation.

solved in $10 \mathrm{ml} 50 \mathrm{mM}$ phosphate buffer $\mathrm{pH}=6.5$. Then 300 mg of Supravalent-Maleimide-HES130/0.5 were dissolved in $20 \mathrm{ml} 50 \mathrm{mM}$ phosphate buffer $\mathrm{pH} 6.5$, added to the peptide solution and vigorously stirred for $2 \mathrm{~h}$ at $37^{\circ} \mathrm{C}$. The peptide excess was removed by size exclusion chromatography on a Superdex 200 column ( 250 x 50mm, $440 \mathrm{ml}$ bed volume) using a $50 \mathrm{mM}$ phosphate buffer pH 6.5 with $500 \mathrm{mM} \mathrm{NaCl}$ as mobile phase. The macromolecular fractions were collected and desalted via a Sephadex G15 column (500 x $50 \mathrm{~mm}, 880 \mathrm{ml}$ bed volume) with desalted water as mobile phase. The collected and combined product fraction was lyophilized and $265 \mathrm{mg}$ of a white solid product, AGEM400 (HES), were obtained.

\section{Cell Lines}

Cell lines TF-1 [26] and BA/F3 were obtained from DSMZ (Braunschweig, Germany), and cultured in RPMI medium with Glutamax (Gibco, Invitrogen, Karlsruhe, Germany) and supplemented with: antibiotics (penicillin/ streptomycin and amphotericin B, Invitrogen); fetal calf serum (FCS, Sigma Aldrich, Taufkirchen, Germany): 20\% for TF-1, and 10\% for BA/F3; and human IL-3 (Peprotech, Hamburg, Germany) or murine IL-3 (Peprotech), respectively. The UT7/EPO cell line, which is a strictly EPOdependent subline of UT7 [27, 28], was a kind gift of Wolfgang Jelkmann (University of Lübeck, Germany). UT7/EPO cells were cultured in DMEM with Glutamax (Invitrogen) supplemented with antibiotics, $10 \% \mathrm{FCS}$, and $3.4 \mathrm{ng} / \mathrm{ml}$ EPO. Cells were passaged every two to three days, always keeping cell densities between 200,000 and 1,500,000 cells $/ \mathrm{ml}$. A large number of aliquots of the cell lines were frozen as soon as possible after receipt from the providers. Cells used for experiments were always between 2 and 4 weeks from the time that they were thawed. Before performing experiments with TF-1 or UT7/EPO cell lines, they were starved for $48 \mathrm{~h}$ in culture medium without cytokine (and in case of TF-1 with a reduced FCS content: $5 \%$ instead of $20 \%$ ). BA/F3 cells did not survive such starvation periods, 
and therefore were cultured in medium with IL-3 until experiments were started.

\section{Cell Survival Assays (MTS Assays)}

The dependence of cell lines on EPO or EPO mimetics for their survival (by stimulation of proliferation and/or inhibition of cell death) was tested using the CellTiter 96 AQ non-radioactive cell proliferation assay (Promega), as described for TF-1 cells elsewhere [29], and measuring the conversion of MTS in colored formazan by viable cells. Starved TF-1 or UT7/EPO cells, or BA/F3 cells taken directly from culture, were plated in multiwell plates in assay medium (the cell lines' culture medium without cytokine, and in case of TF-1, with only 5\% FCS) with differing concentrations of EPO or peptide. UT7/EPO cells were plated at 10,000 cells per well (containing $100 \mu \mathrm{l}$ assay medium per well), TF-1 and BA/F3 cells were plated at 15,000 cells per well. Every substance concentration was tested in triplicate. Assays were incubated for $72 \mathrm{~h}$ before addition of $20 \mu \mathrm{l}$ of MTS reagent per well, and cultured another 2 to $4 \mathrm{~h}$ to develop brown formazan color. Cells were lysed by the addition of $25 \mu \mathrm{l}$ of $10 \%$ SDS per well, and absorbance was measured at $492 \mathrm{~nm}$.

\section{Methylcellulose Cultures}

Development of erythroid colonies and/or erythroid cells from bone marrow cells was studied in methylcellulose media (from StemCell Technologies, Grenoble, France) containing a cocktail of human cytokines (Methocult H4535: with hSCF, hGM-CSF, hIL-3, hIL-6, and hG-CSF). EPO or peptide dilutions were prepared in $20 \mathrm{x}$ stocks in IMDM with $2 \%$ FCS and supplemented with antibiotics, and added as $150 \mu \mathrm{l}$ volumes to Methocult aliquots. Cryopreserved unfractionated human bone marrow cells were obtained from StemCell Technologies. Cryopreserved cynomolgus bone marrow cells were obtained from Covance (Münster, Germany). After thawing and washing, cells were added to aliquots of Methocult in 1/20 volume of IMDM (Invitrogen) with $2 \%$ FCS. Human bone marrow cells were plated at 20,000 cells per well, primate bone marrow cells at 40,000 cells per well. In cases where colonies derived from human bone marrow cells were enumerated, each concentration of EPO or peptide was prepared in $3 \mathrm{ml}$ aliquots, and plated in duplicate: two $1.1 \mathrm{ml}$ volumes were plated in 6-well plates. After 12-14 days, the numbers of CFU-E colonies (less than 200 red cells per colony) or BFU-E colonies (more than 200 red cells per colony) were counted using a microscope. In experiments testing primate bone marrow cells, and in assays in which human progeny cells were also tested by flow cytometry, each concentration was plated only once: from each $1.4 \mathrm{ml}$ aliquot, $1.1 \mathrm{ml}$ was plated. For subsequent evaluation of erythroid cell formation by flow cytometry, excess liquid RPMI medium with $10 \%$ FCS was added to the methylcellulose cultures, which were then liquidified at $4{ }^{\circ} \mathrm{C}$. A fixed number of PE-labeled QuantiBrite beads (BD Biosciences) was added to each sample. After pelleting and washing beads and cells in PBS, cells were stained for $30 \mathrm{~min}$. at RT in PBS containing 5\% FCS and 5\% human serum with FITC-labeled anti-CD36 antibody (diluted 1:10, PeliCluster, Amsterdam) and PE-labeled anti-Glycophorin A antibody (diluted 1:10, Research Diagnostics Inc., Flanders, NJ), or with control mIgG1-FITC (diluted 1:20) and mIgG2a-PE (diluted 1:40, both from Sigma Aldrich). After staining, $0.4 \mathrm{ml}$ PBS was added, and cells were analysed in a FACScalibur flow cytometer. Cellular debris was gated out in the FSC/SSC plot. The numbers of positive cells in the negatively stained samples were subtracted from the marker-positive cells, and normalized against the number of PE-labeled QuantiBrite beads measured in each sample, to yield relative numbers of marker-stained cells.

\section{Phosphorylation of STAT5 and ERK Proteins}

Starved TF-1 or UT7/EPO cells were pelleted and resuspended in medium without cytokine or with given amounts of EPO or peptide, and incubated at $37^{\circ} \mathrm{C}$ for a given period of time. All subsequent steps were performed on ice. Cells were then pelleted, washed with PBS, and lysed for $30 \mathrm{~min}$. on ice in $100 \mu \mathrm{l}$ per 1 million cells lysis buffer: $150 \mathrm{mM}$ $\mathrm{NaCl}, 50 \mathrm{mM}$ Tris/HCl $\mathrm{pH} 8,1 \%$ Triton-X-100, protease inhibitor cocktail (Complete mini, Roche, Mannheim, Germany), and $1 \mathrm{mM}$ orthovanadate. Insoluble material was pelleted, and supernatants were electrophoresed. Lysates were supplemented with reducing Laemmli buffer containing DTT (Invitrogen). Samples were boiled for $5 \mathrm{~min}$. before application to SDS-PAGE gels and electrophoresis. Proteins were electroblotted to PVDF membranes (Invitrogen). Blots were washed, blocked, and incubated with antibodies in Trisbuffered saline with $0.05 \%$ Tween 20 (TBST). After blocking with $3 \%$ skim milk powder (blocking buffer), primary and peroxidase-conjugated secondary antibodies were also diluted in blocking buffer. Detection was performed using the ECL detection kit (GE Healthcare, Freiburg, Germany) and exposure of X-ray films (ECL hyperfilm, GE Healthcare). Antibodies used were: monoclonal mouse anti-P-STAT5 (Cell Signalling Technology, Beverly, USA; 9356) diluted 1:10,000; monoclonal mouse anti-P-Erk (Cell Signalling 9106) diluted 1:10,000; polyclonal rabbit anti-STAT5 (Cell Signalling 9310) diluted 1:5000; polyclonal rabbit anti-Erk (Cell Signalling 9102) diluted 1:25,000; rabbit-anti-mouseHRP (Dako, Hamburg, Germany, P0260) diluted 1:30,000; donkey-anti-rabbit-HRP ECL (GE Healthcare, NA934V) diluted $1: 10,000$.

\section{Radioligand Binding Assay of EPO to Immobilized EPO Receptor}

Competitive binding of $40 \mathrm{pM}{ }^{125} \mathrm{I}-\mathrm{rhEPO}$ (R\&D systems) to Fc-tailed soluble EPO receptor (expressed in NSO cells, R\&D systems) immobilized to SPA beads, in potassium buffer, $\mathrm{pH}$ 7.4, was carried out by adding rhEPO, AGEM400 peptide or AGEM400(HES) in various concentrations. These assays were performed by MDS Pharma (Taipei, Taiwan). The percent inhibition of binding was plotted against concentration of competitor, and concentrations at which half-maximum inhibition was reached (IC50) were calculated using a non-linear, least squares regression analysis. Similarly, the potential of AGEM400 to inhibit binding of 27 different ligand/receptor systems was tested in radioligand binding assays, also from MDS Pharma. For more information on the radioligand binding assays, please check the MDS website (https://discovery.mdsps.com/Catalog/).

\section{Immunizations Against EPO and EMPs}

Rabbits ( $n=2$ per antigen) were immunized at Eurogentec (Seraing, Belgium) with: 1) EPO conjugated to keyhole lim- 
pet hemocyanin (KLH) via amines (lysines); 2) AGEM400 peptide conjugated to KLH via free thiol on the terminal cysteine; or 3) KLH alone. Titers were determined by ELISA against EPO, peptide or KLH ten days after each boost, to determine the optimal time point of the final bleed. Titers of antibodies against KLH were always at least 100 fold higher than those against EPO or peptide. Hematocrit values were determined every two weeks beginning at the first immunization. One out of two rabbits immunized with EPO-KLH developed anemia after the second boost, leading to a hematocrit value of $20 \%$. This animal (SA4893) was sacrificed ten days after the second boost. Hematocrits remained in the normal range for all other rabbits immunized, and these animals were sacrificed ten days after the third boost. Mice $(n=4)$ were immunized at Eurogentec with AGEM400 conjugated to bovine serum albumin (BSA). After three boosts, antibody titers against AGEM400 were still relatively low (near 1:100). Serum was collected from mice sacrificed after the third boost, while hybridomas were also produced with splenocytes of one of the mice. However, no monoclonals were found with a detectable reactivity against AGEM400. Sheep $(n=2)$ were immunized at Charles River (Sulzfeld, Germany) with AGEM400-KLH. Final bleeds were undertaken after the third boost. One of the sheep anti-AGEM400 antisera was affinity purified on an AGEM400 column at Squarix (Marl, Germany).

\section{Western Blot Analysis on Cross-Reactivity of Anti-EPO and Anti-EMP Antibodies}

EPO, BB68 and AGEM400 were electrophoresed and blotted to PVDF membranes, which were incubated with either rabbit antiserum raised against EPO, diluted 1:5000, rabbit antiserum raised against AGEM400, diluted 1:200, or mouse antiserum raised against AGEM400, diluted 1:500. This was followed by incubation with donkey-anti-rabbitHRP ECL (GE Healthcare, NA934V) diluted 1:10,000 or rabbit-anti-mouse-HRP (Dako, Hamburg, Germany, P0260) diluted 1:30,000, and development with ECL detection kit (GE Healthcare, Freiburg, Gemany).

\section{Inhibition of Biological Activity by Soluble EPO Recep- tor or by Rabbit Antisera}

MTS assays testing the in vitro effect of EPO or AGEM400(HES) were performed with TF-1 or UT7/EPO cells as described above. In addition, however, soluble recombinant EPO receptor (Sigma Aldrich), or antisera were added. Soluble EPO receptor was added to $2 \mu \mathrm{g} / \mathrm{ml}$. Rabbit anti-EPO antiserum SA4893 or pre-immune serum from the same animal was added to $1 \%$.

\section{Sandwich ELISA to Detect EMP}

Multiwell (96-well) plates (Greiner Bio-One 655161, Kremsmünster, Austria) were shortly equilibrated in $100 \mu \mathrm{l}$ PBS, and then coated with $100 \mu \mathrm{l} 5 \mu \mathrm{g} / \mathrm{ml}$ affinity-purified sheep-anti-AGEM400 antibody diluted in (Dulbecco's) PBS for $1 \mathrm{~h}$ at RT. Wells were washed three times with $100 \mu \mathrm{l}$ PBS. Dilutions of AGEM400 or AGEM400(HES) were added in $50 \mu \mathrm{l}$ volumes, and incubated for $1 \mathrm{~h}$ at RT. Each dilution was tested in triplicates. Wells were washed three times with PBS. Blocking solution (PBS with $2 \%$ skim milk powder (Merck, Darmstadt, Germany) was added in $200 \mu \mathrm{l}$ volumes, and incubated for $1 \mathrm{~h}$ at RT. After removal of blocking solution, rabbit-anti-AGEM400 antiserum, diluted 1:1000 in PBS was added in $100 \mu \mathrm{l}$ volumes. The solution was then incubated with antiserum for $1 \mathrm{~h}$ at RT. In the meantime, secondary antibody (donkey-anti-rabbit-HRP ECL, GE Healthcare, NA934V) was pre-incubated as a 1:1000 dilution in blocking solution with $10 \%$ pooled human serum for $45 \mathrm{~min}$. at $\mathrm{RT}$ to reduce background reactivity with serum proteins. After the incubation with primary antibody, wells ware washed three times with PBS, after which pre-incubated secondary was added in $100 \mu \mathrm{l}$ volumes, and incubated for $1 \mathrm{~h}$ at RT. Wells were washed three times with PBS, and $100 \mu \mathrm{l}$ volumes of TMB reagent (s(HS)TMB, SDT, Baesweiler, Germany) were added, and incubated until blue color development became apparent. The reaction was stopped by adding $100 \mu \mathrm{l} /$ well of $1 \mathrm{~N} \mathrm{HCl}$, and absorbance was measured at $450 \mathrm{~nm}$.

\section{RESULTS}

\section{Optimization of the EMP}

The sequence of the final monomeric EMP, BB68, was chosen after testing several hundreds of different 20-mer peptides for their efficacy in the TF-1 MTS assay. BB68 was among the most potent peptides, and was chosen also because of its clear sequence differences with the published EMP-1 sequence $[5,23]$. BB68 contains lysines instead of prolines in positions 10 and 17; it also contains a 1naphthalalanine instead of a tryptophane in position 13 . The dimeric version of the peptide, AGEM400, was synthesized as a continuous 41-mer, in which the C-terminus of one monomer was connected by a peptide bond to the $\mathrm{N}$ terminus of the other monomer. This dimerization strategy differs from those published elsewhere [24, 30], where coupling of both $\mathrm{N}$-termini or of both $\mathrm{C}$-termini and linkers to obtain dimeric peptides were used. The C-terminus of AGEM400 contains an additional of a tBu-blocked cysteine which, after deblocking, allows for conjugation to maleimide-activated macromolecules such as HES. A scheme of monomeric, dimeric, and HES-conjugated peptide is presented in Fig. (1).

\section{Comparison of Efficacy of Monomeric, Dimeric and HES-Conjugated EMP in Vitro}

Tested on the human EPO-responsive cell lines TF-1 and UT7/EPO, dimeric peptide AGEM400 showed an efficacy that was about 100-fold higher than that of monomeric peptide BB68, leading to EC50 values for AGEM400 close to 1 $\mathrm{ng} / \mathrm{ml}$, and close to that of EPO, in both assay systems (Fig. 2, Table 1). Conjugation of AGEM400 peptides to HES led to a further small, but reproducible, improvement of the peptide's efficacy. In the TF-1 assay, the average EC50 decreased by a factor of 4 , while in the UT7/EPO assay, the average EC50 decreased by a factor of 1.6. The EC50 values of AGEM400(HES) in both assay systems went down to 0.66 and $0.45 \mathrm{ng}$ peptide/ml, respectively (Table 1), corresponding to 140 - $100 \mathrm{pM}$ dimeric peptide (MW $4.6 \mathrm{kDa}$ ). When molarity of the AGEM400(HES) conjugate was considered (mean molecular mass of AGEM400(HES) was $150,000 \mathrm{Da})$, the EC50 in the TF-1 or UT7/EPO assays was between 20 and $30 \mathrm{pM}$ conjugate, which was similar to the molar EC50 values found for EPO (see also Fig. (2) right hand upper panel for this graphical representation). It should 
UT7/EPO MTS

Protein/peptide concentration
UT7/EPO MTS

Molarity whole molecules

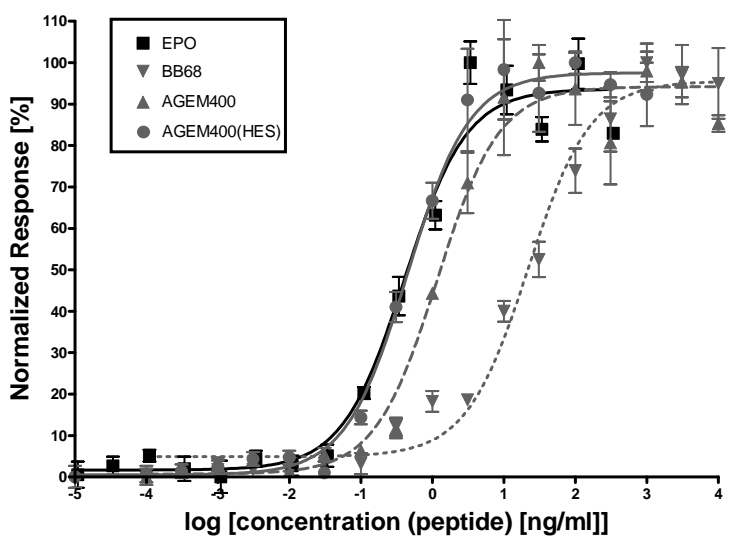

TF-1 MTS

Protein/peptide concentration

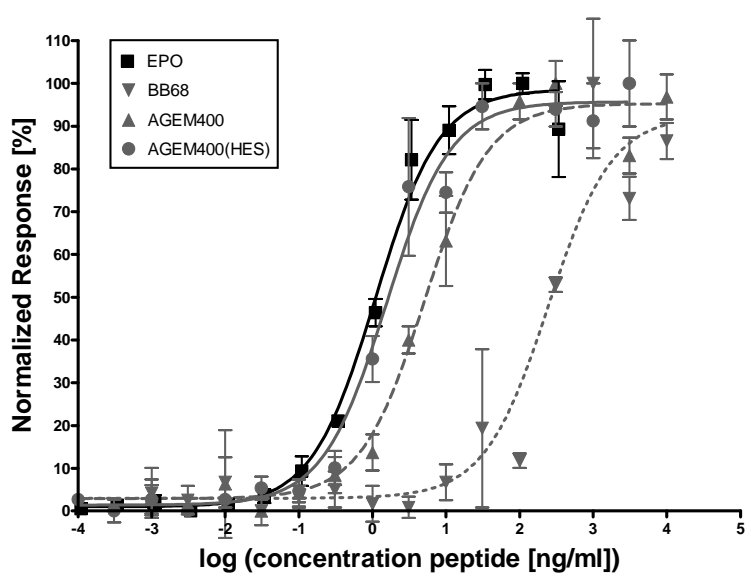

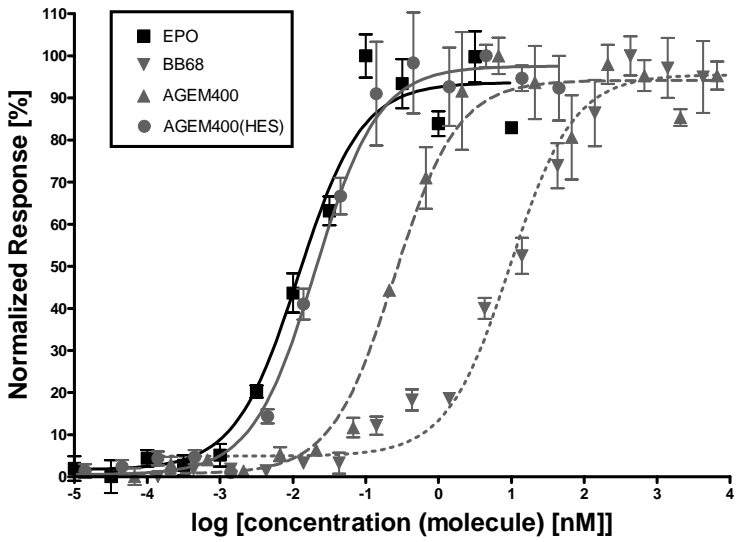

BA/F3 MTS Protein/peptide concentration

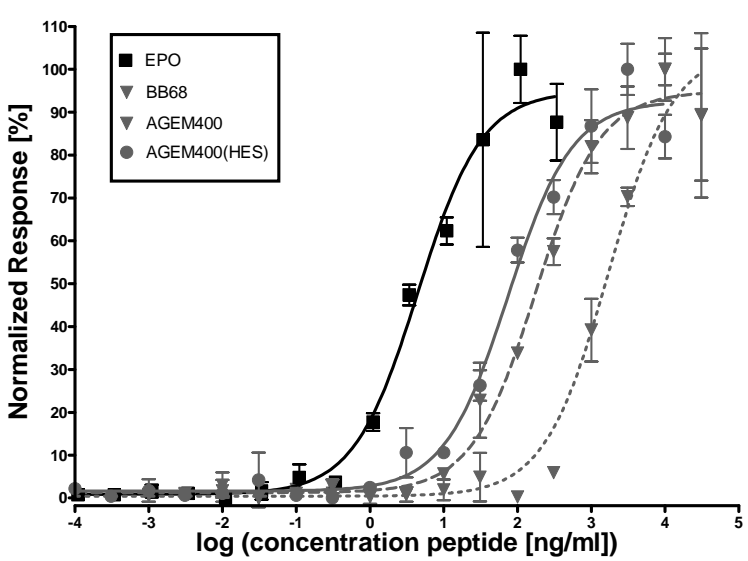

Fig. (2). Assays comparing the efficacy of EPO and EPO mimetics in stimulating cell survival. Human UT7/EPO cells (both top panels), human cell line TF-1 (left hand bottom panel), or murine BA/F3 cells (right hand bottom panel) were incubated with varying concentrations of agents (usually shown as $\mathrm{ng} / \mathrm{ml}$ protein or peptide, considering the peptide content of AGEM400(HES) to be $10 \% \mathrm{w} / \mathrm{w}$ ). In the right hand top panel, molar concentrations of whole molecules are shown, whereby it should be noted that 1 mole of AGEM400 contains 2 moles of monomeric BB68, while 1 mole of AGEM400(HES) contains on average 5 moles of AGEM400. Values represent means and standard deviations of triplicate measurements. The EC50 values, the numbers of experiments performed with each substance and in each cellular model are given in Table 1. Absorbance values measured were normalized to values between 0 and $100 \%$ response, to facilitate calculation of EC50

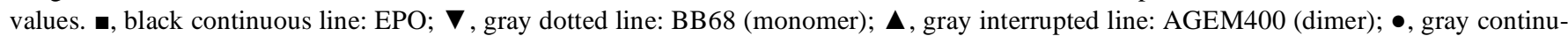
ous line: AGEM400(HES). Note that both dimerization of the peptide, and conjugation to HES, increased the efficacy per ng peptide, in each of the assay systems.

be noted, however, that one mole of HES contained, on average, 4-5 moles of AGEM400 peptide. Representation of the efficacy of AGEM400(HES) in molar concentrations can therefore easily lead to confusion if it is not specified whether conjugate molarity or peptide molarity is being described. The assays using murine cell line BA/F3 yielded an efficacy for EPO that was much lower (EC50 about 10-fold higher) than in the assays using human cells, and the efficacy of peptide and AGEM400(HES) was also poorer, even in comparison to that measured with EPO. The increase in efficacy due to dimerization of the peptide was only about 10fold in the murine assay, while a 2.4 fold increase in efficacy was obtained by conjugation to HES (Fig. 2, Table 1). The average EC50 of AGEM400(HES) was $75.5 \mathrm{ng}$ peptide/ml in the BA/F3 assay, which was more than 10 fold higher than that of EPO.

\section{Stimulation of Erythropoiesis from Bone Marrow Cells in Methylcellulose}

The stimulation of red colonies (CFU-E and BFU-E) or erythroid cells from bone marrow precursor cells in methylcellulose assays is a process that includes stimulation of proliferation, inhibition of apoptosis as well as stimulation of erythroid differentiation. Both EPO and EMP stimulated the development of CFU-E and BFU-E colonies dosedependently. Dimeric AGEM400 and AGEM400(HES) were more efficient stimulators than monomeric BB68, also in this assay type (Fig. 3). EPO started to stimulate the development 
of CFU-E and BFU-E colonies from human bone marrow cells at concentrations below $1 \mathrm{ng} / \mathrm{ml}$. BB68 started to show activity at concentrations between 100 and $1000 \mathrm{ng} / \mathrm{ml}$, while AGEM400 required concentrations of at least 10 $\mathrm{ng} / \mathrm{ml}$. AGEM400(HES) worked at concentrations between 1 and $10 \mathrm{ng} / \mathrm{ml}$ peptide and had an efficacy similar to that of Aranesp (Fig. 3). Similar dose-effect relationships were found for EPO and AGEM400(HES) when using bone mar- row cells derived from cynomolgus monkeys (Fig. 3). Quantitative measurement of erythropoiesis from human bone marrow cells was also performed by flow cytometry, after liquidification of the methylcellulose media and staining of erythroid cells with antibodies against erythroid cell markers CD36 and glycophorin A (GPA). Dose-effect curves after flow cytometry showed similar shapes as those obtained after counting of colonies (Fig. 3).

Table 1. Mean EC50 Values. EC50 Values (in ng/ml Peptide), and Standard Deviations Thereof in $\mathbf{n}$ Experiments are Shown, of EPO, BB68 (Monomeric Peptide), AGEM400 (Dimeric Peptide) and AGEM400(HES) in MTS Assays on TF-1 cells, UT7/EPO Cells and BA/F3 Cells

\begin{tabular}{|c|c|c|c|c|c|c|c|c|c|}
\hline & \multicolumn{3}{|c|}{ TF-1 } & \multicolumn{3}{|c|}{ UT-7/EPO } & \multicolumn{3}{|c|}{ BA/F3 } \\
\hline & EC50 [ng/ml] & SD & $\mathbf{n}$ & $\operatorname{EC50}[\mathrm{ng} / \mathrm{ml}]$ & SD & $\mathbf{n}$ & EC50 [ng/ml] & SD & $\mathbf{n}$ \\
\hline EPO & 0.874 & 0.527 & 66 & 0.543 & 0.354 & 20 & 6.78 & 4.59 & 53 \\
\hline BB68 & 248.9 & 145.8 & 66 & 49.80 & 16.93 & 11 & 1909 & 1151 & 55 \\
\hline AGEM400 & 2.650 & 1.120 & 54 & 0.699 & 0.299 & 18 & 181.2 & 111.3 & 38 \\
\hline AGEM400(HES) & 0.660 & 0.232 & 15 & 0.449 & 0.305 & 27 & 75.53 & 46.18 & 6 \\
\hline
\end{tabular}

Methylcellulose human BM cells BFU-E colonies ( ) and CFU-E colonies (--)

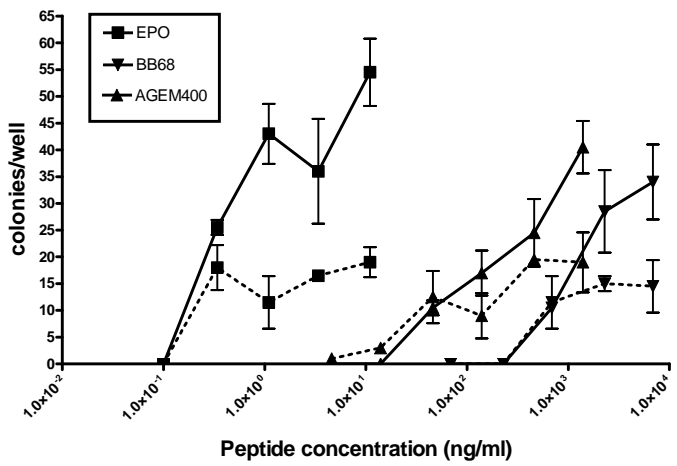

Methylcellulose human BM cells CD36+ cells $(\perp$ ) and Glycophorin A+ cells (--)

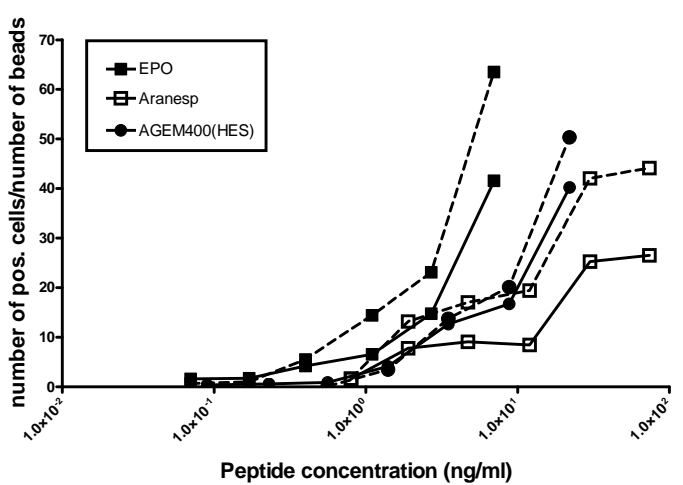

Methylcellulose human BM cells BFU-E colonies ( ) and CFU-E colonies (--)

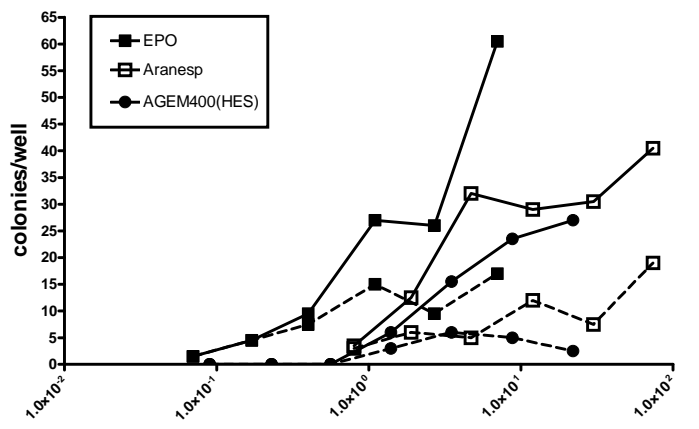

Peptide concentration (ng/ml)

Methylcellulose Cynomolgus BM BFU-E colonies ( $)$ and CFU-E colonies (--)

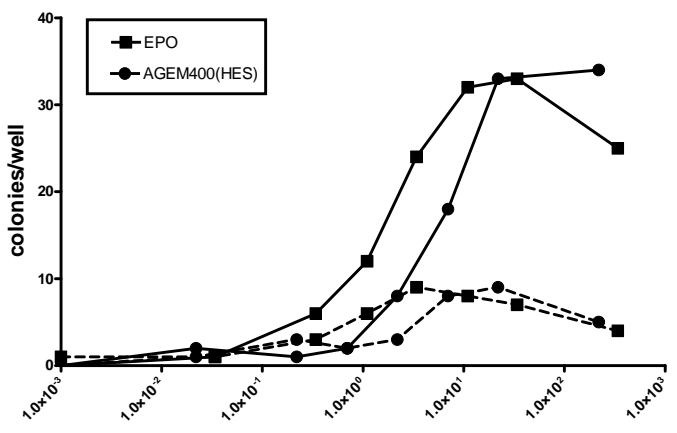

Peptide concentration (ng/ml)

Fig. (3). Clonogenic assay to measure development of red colonies from human bone marrow cells (or cynomolgus bone marrow cells: right hand bottom panel) in methylcellulose medium under the influence of erythropoieis stimulating agents. Red colonies (CFU-E, dotted lines; and BFU-E, continuous lines) were enumerated microscopically, or cells were recovered from liquidified media, stained with antibodies against erythroid markers (CD36: continuous lines; glycophorin A: dotted lines), and analysed by flow cytometry (left hand bottom panel). п: EPO; $\square$ : Aranesp; $\mathbf{\nabla}$ : BB68 (monomer); $\boldsymbol{\Delta}$ : AGEM400 (dimer); $\bullet$ : AGEM400(HES). The experiment shown in the left hand top panel shows means and standard deviations from duplicate measurements, the other data points (without error bars) reflect single determinations. Typical examples are shown of experiments performed at least three times. Human cells were from different donors each time. 


\section{Signalling Through STAT5 and ERK in UT7/EPO}

Phosphorylation of signalling molecules such as STAT5 and ERK in UT7/EPO cells occurs with similar efficacy and kinetics by EPO, AGEM400 or AGEM400(HES). STAT5 phosphorylation was tested after 30 minute incubations with increasing concentrations of these agents. Maximum signals were obtained with $3.4 \mathrm{ng} / \mathrm{ml}$ or more EPO, $4.6 \mathrm{ng} / \mathrm{ml}$ or more AGEM400 and $2.2 \mathrm{ng}$ peptide/ml or more AGEM400 (HES) (Fig. 4, upper panel). Incubation of UT7/EPO cells for different periods of time with $3.4 \mathrm{ng} / \mathrm{ml}$ EPO or $10 \mathrm{ng}$ peptide/ml AGEM400(HES) showed the strongest P-STAT5 signals after 30 minutes, which decreased upon prolonged incubation. After $24 \mathrm{~h}$ of incubation, P-STAT5 signals caused by EPO or AGEM400(HES) were much weaker than the signals observed after 30 minutes, but still equally strong after incubation with EPO or with AGEM400(HES) (Fig. 4, bottom panel). ERK (MAPK p42/p44) was also phosphorylated equally strong by EPO or AGEM400(HES) after 30 minutes, but P-ERK signals disappeared much faster than the P-STAT5 signals, making P-ERK difficult to detect after $4 \mathrm{~h}$ or $24 \mathrm{~h}$ of incubation.

\section{Evidence for Binding of AGEM400(HES) to the EPO Receptor}

Addition of $2 \mu \mathrm{g} / \mathrm{ml}$ soluble recombinant EPO receptor (sEPO-R) to TF-1 or UT7/EPO MTS assays inhibited the in vitro effects of both EPO and AGEM400(HES), clearly shown in Fig. (5) (top and central panel) by right shifts of the dose-effect curves. In contrast, sEPO-R did not influence the dose-effect curve of IL-3 in the TF-1 MTS assay (Fig. 5, central panel). This data indicates binding of both EPO and AGEM400(HES) to the soluble EPO receptor. Radioligand binding assays, in which binding of iodine-labeled EPO to recombinant EPO receptor was competed for by increasing concentrations of EPO, AGEM400 or AGEM400(HES), showed concentration-dependent inhibition of binding caused by all three agents at similar efficacies. While EPO had an IC50 of close to $10 \mathrm{ng} / \mathrm{ml}$, AGEM400 and AGEM400 (HES), under the same circumstances, showed IC50 values of $18 \mathrm{ng} / \mathrm{ml}$ and $13.5-16 \mathrm{ng}$ peptide/ml, respectively (Table 2). The increased efficacy of AGEM 400 conjugated to HES compared to AGEM400 as a free dimeric peptide in the in vitro assays shown in Fig. (2) was thus not reflected in an increased potency of AGEM400(HES) to replace EPO from its receptor compared with peptide alone.

AGEM400 peptide also competed for binding of 8 other ligands to their respective receptors, but only with relatively high IC50 values of between $1.2 \mu \mathrm{g} / \mathrm{ml}$ and $34.8 \mu \mathrm{g} / \mathrm{ml}$. AGEM400 peptide was unable to inhibit to $50 \%$ or more the binding of 19 more ligand/receptor systems at $10 \mu \mathrm{M}(47$ $\mu \mathrm{g} / \mathrm{ml}$ ). This data is listed in Table 3 .

\section{No Cross Reaction Between Antibodies Against EPO or Against AGEM400}

During the generation of rabbit polyclonal antibodies against EPO, one of the animals immunized with EPO-KLH became anemic. The procedure was ceased when this rabbit reached a hematocrit of $20 \%$. The serum of this rabbit (SA4893) appeared to contain neutralizing anti-EPO antibodies, because addition of $1 \%$ of this serum to TF- 1 MTS assays completely abolished the activity of up to $3.4 \mathrm{ng} / \mathrm{ml}$ EPO. Pre-immune serum from the same animal did not inhibit the activity of EPO (Fig. 6, upper panel). However, the neutralizing anti-EPO antiserum did not inhibit the activity of AGEM400(HES) at all (Fig. 6, central panel). This indicates that these neutralizing anti-EPO antibodies do not neu-

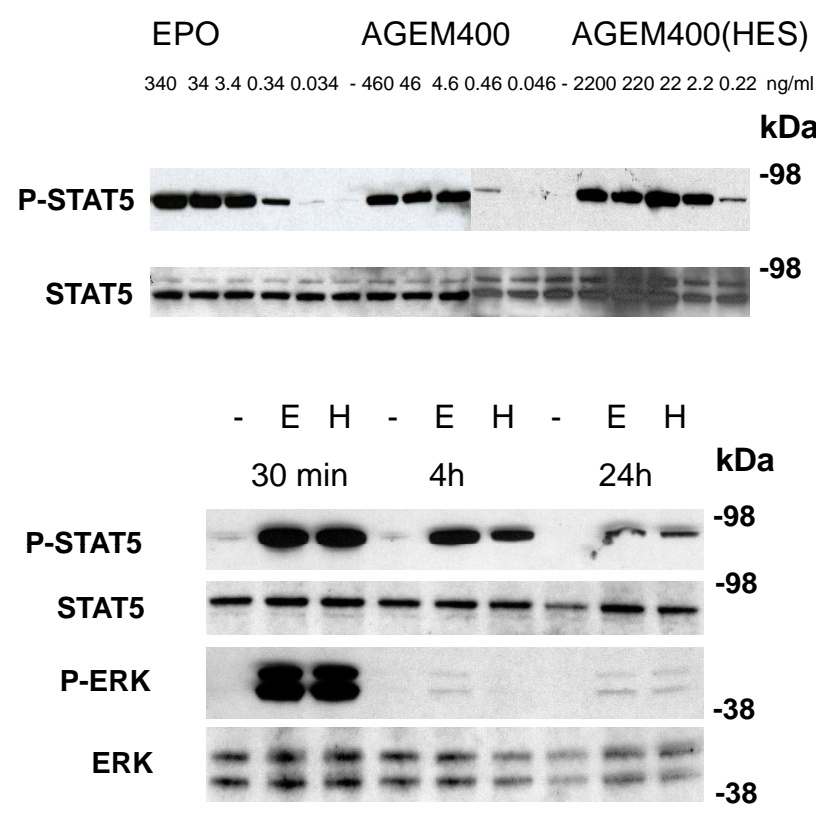

Fig. (4). Western blot analysis studying STAT5 phosphorylation and/or ERK phosphorylation in UT7/EPO cells. Top: Concentration dependency of STAT5 phosphorylation: starved UT7/EPO cells were incubated for $30 \mathrm{~min}$. at $37^{\circ} \mathrm{C}$ with EPO, AGEM400 peptide, or AGEM400(HES) at various concentrations (denoted in $\mathrm{ng} / \mathrm{ml}$ protein/peptide), or no stimulus at all (-). Bottom: Persistence of phosphoSTAT5 and phospho-ERK signals after continuous incubation of UT7/EPO cells with $3.4 \mathrm{ng} / \mathrm{ml} \mathrm{EPO} \mathrm{(E),} 10 \mathrm{ng} / \mathrm{ml}$ (peptide concentration) AGEM400(HES) (H), or no stimulus (-) for $30 \mathrm{~min}$., 4h, or 24h. Blots containing electrophoresed cell lysates were probed with antibodies against phospho-STAT 5 (P-STAT5), total-STAT 5 (STAT5), phospho-ERK (P-ERK), or total-ERK (ERK). Typical examples are shown of experiments performed at least twice. 
UT7/EPO MTS

Inhibition of activity by soluble EPO-R

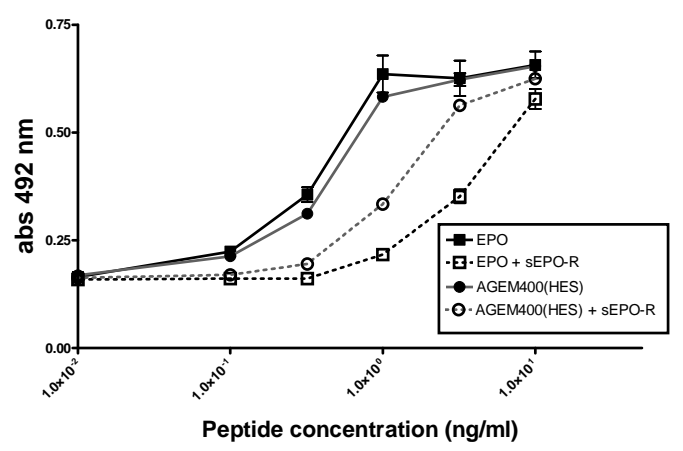

TF-1 MTS

Inhibition of activity by soluble EPO-R

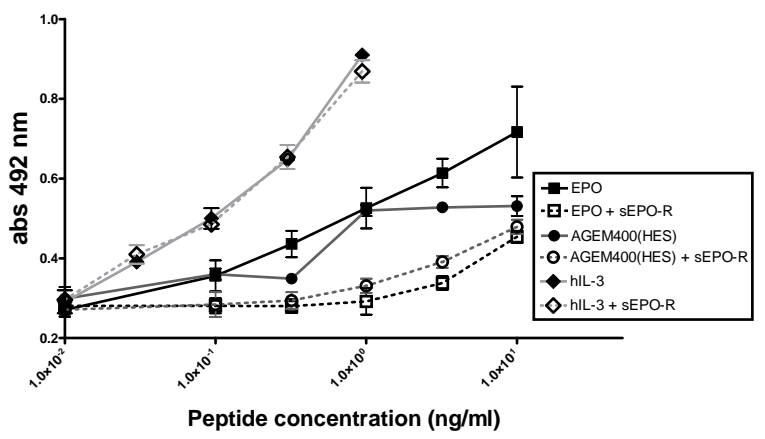

Radioligand binding assay Inhibition of binding of ${ }^{125}$ I-EPO to EPO-receptor

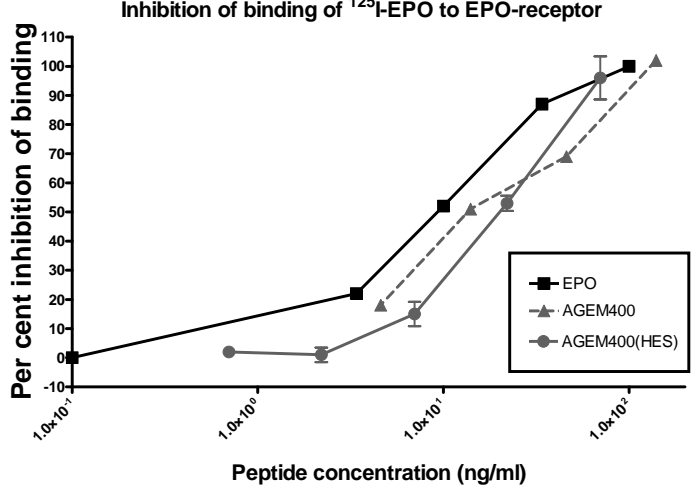

Fig. (5). Evidence for binding of AGEM400 and AGEM400(HES) to the EPO receptor. Top: UT7/EPO MTS assay showing the dosedependent effects of EPO ( $\bullet$, black lines) and AGEM400(HES) ( $\bullet$, gray lines) on cell survival, and the inhibition of these effects (right shift of dose-effect curves) by addition of $2 \mu \mathrm{g} / \mathrm{ml}$ soluble EPO receptor (sEPO-R, open symbols and dotted lines). Center: TF-1 MTS assay assay showing the dose-dependent effects of EPO ( $\bullet$, black lines), AGEM400(HES) ( $\bullet$, gray lines) and IL-3 ( $\diamond$, bright gray lines) on cell survival, and the inhibition of the effects of EPO and AGEM400(HES) - but not of IL-3 - by addition of $2 \mu \mathrm{g} / \mathrm{ml}$ soluble EPO receptor (sEPO$\mathrm{R}$, open symbols and dotted lines). Data points in the MTS graphs reflect means of triplicate measurements and error bars reflect the standard deviations. Experiments were performed twice with similar outcomes. Bottom: Radioligand binding assay performed on bead-immobilized dimeric Fc-tailed recombinant soluble EPO receptor (R\&D systems). Binding of radiolabeled rhEPO (R\&D systems; $40 \mathrm{pM})$ was competed

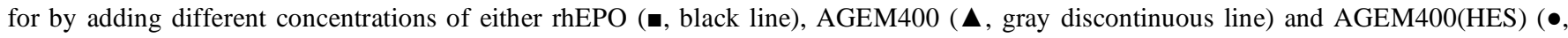
gray line). Inhibition of binding was plotted as a percent value against the concentration of competitor (in ng protein or peptide per ml). Inhibition of binding by AGEM400(HES) was measured three times within this experiment, of which means and standard deviations are depicted. IC50 values and statistics of $n$ experiments are listed in Table 2.

tralize EMP. Rabbit-anti-EPO antiserum stained EPO but not BB68 or AGEM400 peptide on Western blots (Fig. 6, bottom panel). Likewise, polyclonal rabbit-anti-AGEM400 antiserum and polyclonal mouse-anti-AGEM400 antiserum stained BB68 and AGEM400 peptide, but not EPO. These results indicate that there is no cross-reactivity between antibodies against EPO or against AGEM400, at least in the animal models tested here. 
Table 2. Inhibition Efficiencies of Binding of Radiolabeled EPO to EPO Receptor. Inhibition Efficiencies are Expressed as the IC50 Values (in ng Protein or Peptide/ml), with Standard Deviations in n Experiments. For rhEPO (Molecular Mass 34 kDa) and AGEM400 (Molecular Mass $4.6 \mathrm{kDa}$ ) only Inter-Assay Variability is Given of Assays in which Each Substance was Measured once. For AGEM400(HES) Both Inter-Assay Variability (2 Experiments) and Intra-Assay Variability (Triplicate Measurement within an Experiment) are Given

\begin{tabular}{|c|c|c|c|}
\hline \multicolumn{2}{|c|}{ Inhibition of Binding of Radiolabeled EPO to EPO Receptor } \\
\hline Agent & IC50 [ng/ml] & SD & n \\
\hline \hline rhEPO & 9.69 & 1.43 & 4 \\
\hline AGEM400 & 17.99 & 3.73 & 2 \\
\hline AGEM400/HES (interassay) & 16.05 & 3.60 & 2 \\
\hline AGEM400/HES (intraassay) & 13.52 & 0.63 & 3 \\
\hline
\end{tabular}

Table 3. Efficiencies of AGEM400 Peptide to Inhibit Binding of Radiolabeled Ligands to Their Respective Receptors. If Inhibition Efficiencies could be Quantified, These are Expressed as the IC50 Values (in ng Peptide/ml), with the Standard Error of Means of Duplicate Measurements. On the Left Hand Side, 8 Ligand/Receptor Systems are Listed in which AGEM400 Peptide Inhibited Quantitatively. The Three Right Hand Columns List 19 Ligand/Receptor Systems in which AGEM400 Peptide was not Able to Inhibit More Than $50 \%$ of the Binding at a Concentration of $47 \mu \mathrm{g} / \mathrm{ml}$

\begin{tabular}{|c|c|c|c|c|c|}
\hline Inhibition of Binding of & & & \multirow[t]{2}{*}{ No Inhibition of Binding } & \multirow[t]{2}{*}{ No Inhibition of Binding } & \multirow[t]{2}{*}{ No Inhibition of Binding } \\
\hline Specific Ligand/Receptor System & $\operatorname{IC50}[\mu \mathrm{g} / \mathrm{ml}]$ & $\mathrm{SEM}[\mu \mathrm{g} / \mathrm{ml}]$ & & & \\
\hline Bradykinin B1 & 3.61 & 0.48 & Adrenergetic $\alpha 1 \mathrm{D}$ & Histamine $\mathrm{H} 1$ & Tachykinin NK1 \\
\hline Vasopressin V1B & 20.4 & 1.3 & Endothelin ETA & Leukotrine & \\
\hline Chemokine CCR1 & 16.7 & 3.3 & EGF & Melatonin MT1 & \\
\hline Neuromedin U NM U1 & 30.7 & 5.1 & GABA B1A & Muscarinic M1 & \\
\hline
\end{tabular}

\section{Bioanalytics of AGEM400(HES)}

A sandwich ELISA was developed with a limit of detection close to $1 \mathrm{ng} / \mathrm{ml}$ peptide for AGEM400 conjugate, and in the low ng/ml range for AGEM400 peptide on its own (Fig. 7). AGEM400 peptide or AGEM400(HES) could be diluted in various buffers, media or sera, and were effectively detected in all of them, albeit with varying levels of detection.

\section{DISCUSSION}

We present here the in vitro effects, and a partial characterization of the working mechanism of a novel EMP in its monomeric (BB68) and dimeric forms (AGEM400), and of a conjugate of multiple AGEM400 peptides to HES (AGEM400 (HES)).

The sequence of BB68 differed in three positions from EMP-1 [5], and these three exchanged residues (Pro10, Trp13 and Pro17) were considered part of the critical core of EMP-1 [23]. However, AGEM400(HES) is more than just another EMP with a sequence a little different from that of other EMPs, and dimerized in a different fashion than used for other EMPs [9, 24, 30]. The AGEM400 peptide was conjugated to HES in such a way that on average 5 dimeric peptides were bound to one HES molecule. The primary purpose of the conjugation to HES was to increase molecular mass and in vivo half life. However, it is shown here that conjugation to HES also increased the efficacy of the AGEM400 peptide by a factor of between 1.6 and 4, depending on the assay system in which it was tested. A likely explanation for the observed increase in efficacy of AGEM400 peptide due to conjugation to HES is the so-called multivalency principle: once one peptide has bound to the EPO receptor, other peptides present on the same macromolecule will find and bind consecutive EPO receptors faster, while multiple peptides on one macromolecule binding to multiple receptors will have a lower off-rate as a whole than the same number of free peptides. This principle has been described for other EPO receptor-binding peptides in Vadas et al. [31]. However, we were not able to demonstrate more efficient replacement of EPO from the EPO receptor by AGEM400 conjugated to HES than by AGEM400 peptide on its own. In 
TF-1 MTS

EPO with/without rabbit antisera 1:100

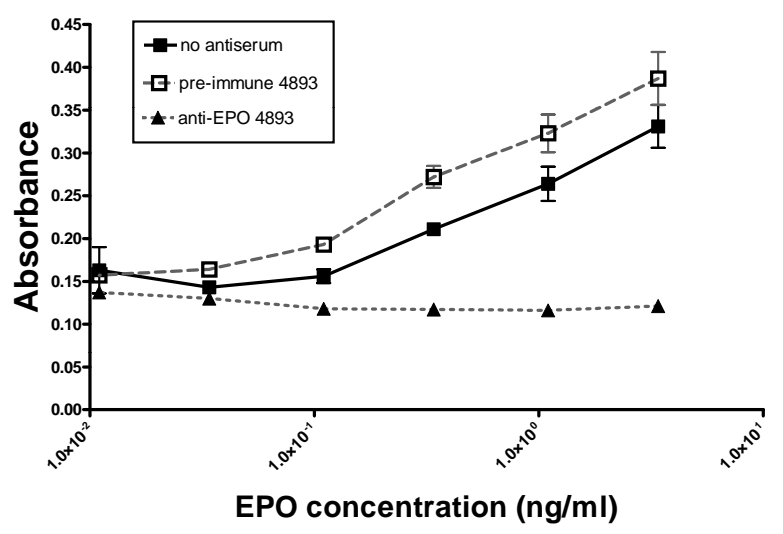

TF-1 MTS

AGEM400(HES) w/wo rabbit antisera 1:100

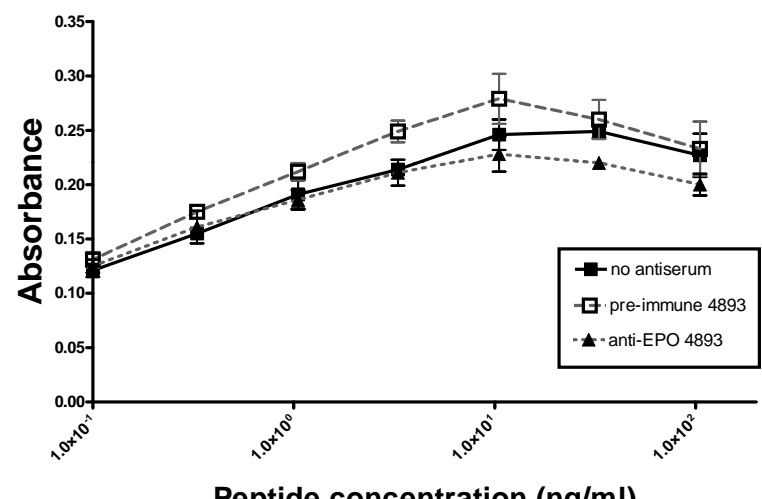

Peptide concentration $(\mathrm{ng} / \mathrm{ml})$
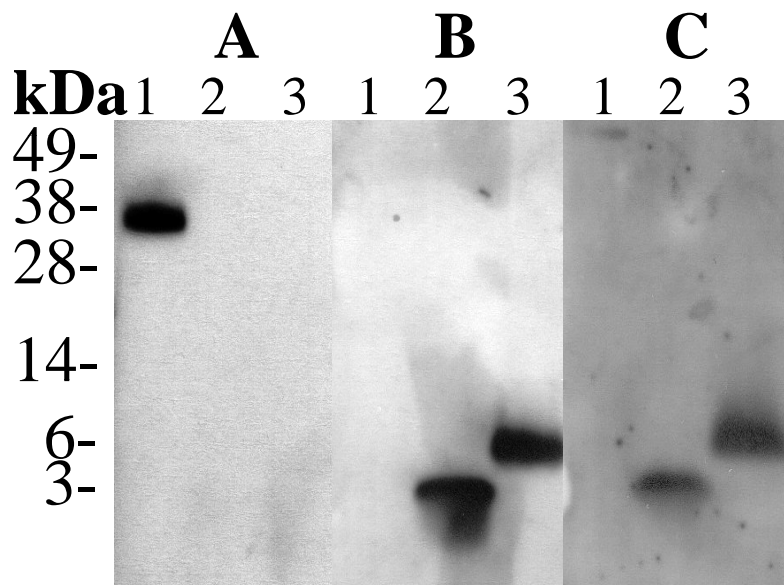

Fig. (6). Immunological distinction between EPO and AGEM400. Top: Inhibition of the survival-promoting effect of up to $34 \mathrm{ng} / \mathrm{ml}$ (1 $\mathrm{nM}$ ) EPO on TF-1 cells in the MTS assay by addition of rabbit anti-EPO antiserum ( $\boldsymbol{\nabla}$, dotted gray line) but not by $1 \%$ pre-immune serum from the same rabbit ( $\square$, discontinuous gray line). Middle: No inhibition of the survival-promoting effect of up to $100 \mathrm{ng} / \mathrm{ml}$ (peptide concentration) AGEM400(HES) on TF-1 cells in the MTS assay by addition of $1 \%$ rabbit anti-EPO antiserum ( $\boldsymbol{\nabla}$, dotted gray line) or $1 \%$ pre-immune serum from the same rabbit ( $\square$, discontinuous gray line). $\mathbf{m}$, black continuous lines: no rabbit serum added. The higher absorbances observed with the pre-immune serum are probably caused by endogenous EPO in this rabbit serum (which is neutralized in the anti-EPO antiserum). Data points in the MTS graphs reflect means of triplicate measurements and error bars reflect the standard deviations. Experiments were performed twice with similar outcomes. Bottom: Western blot demonstrating the reactivity of several antisera with either EPO (13 ng in lanes 1), monomeric peptide BB68 (750 ng in lanes 2) or AGEM400 (750 ng in lanes 3). Blots were stained with a rabbit antiserum raised against Erypo, diluted 1:5000 (A); rabbit antiserum raised against AGEM400, diluted 1:200 (B); or mouse antiserum raised against AGEM400, diluted 1:500 (C), followed by incubation with an appropriate secondary antibody conjugated to horseradish peroxidase (HRP), and development with a chemiluminescent substrate. Typical examples are shown of experiments performed at least twice. 

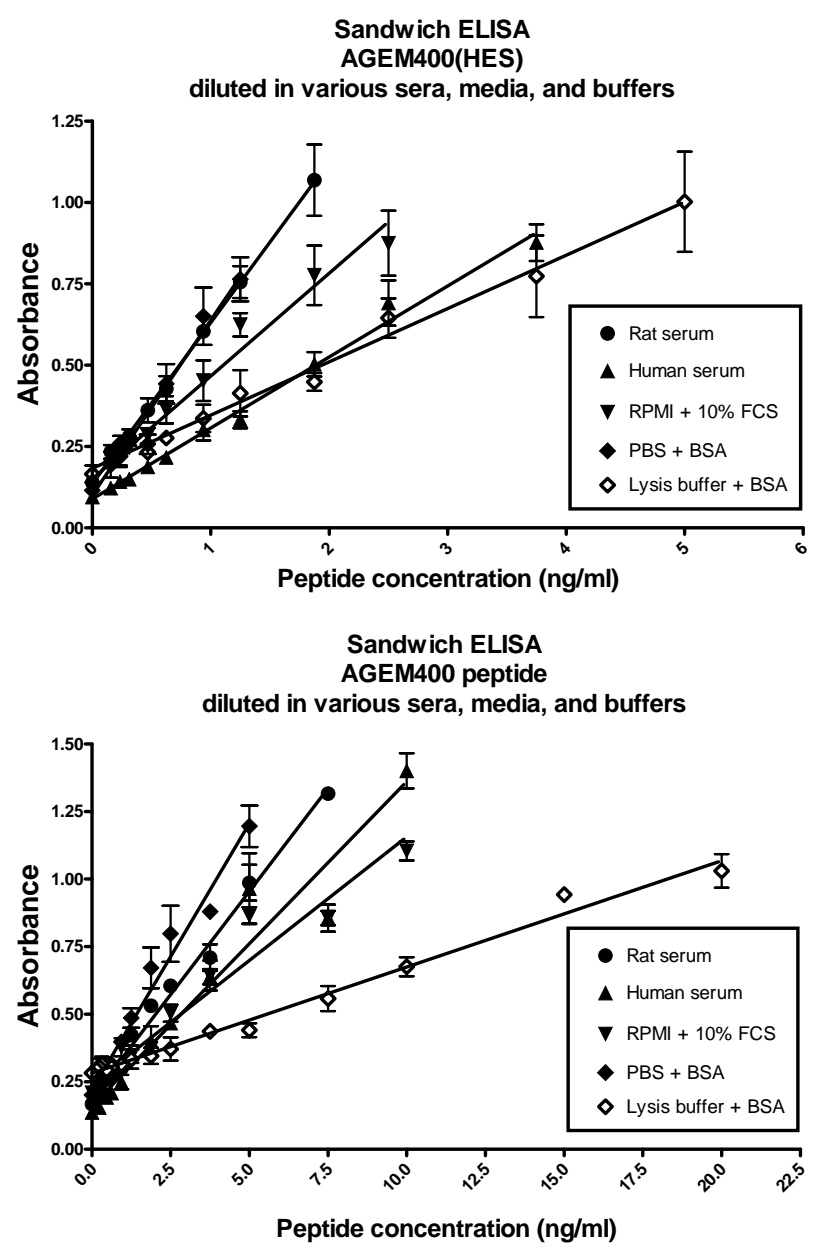

Fig. (7). Sandwich ELISA demonstrating efficient detection of AGEM400 peptide (upper panel) or AGEM400(HES) (concentrations depicted in ng peptide/ml; bottom panel). Substances were diluted in various relevant dilution media: rat serum $(\bullet)$; human serum $(\boldsymbol{\Delta})$; RPMI + $10 \%$ FCS ( $)$; PBS + 1\% BSA ( $\bullet$ ); lysis buffer + 1\% BSA ( $\square)$. Shown are means and standard deviations of triplicate measurements. Typical examples are shown of experiments performed at least twice.

fact, IC50 values were similar for AGEM400 peptide and for AGEM400 HES conjugate. Finding the cause for the improved efficacy of AGEM400(HES) as compared with AGEM400 peptide will be a topic for further study. Interestingly, coupling of a dimeric EMP to PEG [8] led to a substance, Hematide, with a five-fold decreased receptor binding affinity as well as decreased in vitro efficacy, as compared to peptide only.

A further difference between peptide conjugation to PEG or to HES is that high molecular weight PEG is not biodegradable while the majority of high molecular weight HES is hydrolysed by amylase and degradation products are renally excreted (reviewed in Boldt [22]). While HES is used as active ingredient in plasma expander solutions on daily basis in many clinical settings worldwide, high-molecular weight PEG is not suited as plasma expander due to the lack of biodegradability and accumulation. The biodegradability of HES, and connected with this its plasma clearance and its elimination half-life, is primarily controlled by the $C_{2} / C_{6}$ degree of substitution [32, 33]. Use of HES as plasma expander is a high-dose application involving daily doses up to tens of grams of HES. Under these circumstances, there are some reports on accumulation of HES in various organs, especially of those HES grades with high ratios of substitu- tion [33, 34]. Repeated HES administration as high-dose plasma expander can also lead to impaired renal function, hemostatic problems, itching, and anaphylactic reactions [22, 35], but HES with low degrees of substitution do not show significant accumulation and are generally well tolerated, even after repeated administration [22, 36-38]. All the reports of side effects refer to applications that use HES doses more than 1000 times higher than those expected to be effective for a HES-conjugate like AGEM400(HES). It should be noted that pharmacokinetic and toxicology studies with HES were performed in rats, pigs and humans in single or repeated doses of 0.5 to $1 \mathrm{gram} / \mathrm{kg}$, while AGEM400(HES) is anticipated to be effective against anemia in doses well below $1 \mathrm{mg} / \mathrm{kg}$. Therefore, there are no concerns that the HES component of AGEM400(HES) would accumulate in the body - even in a dialysis patient - avoiding any long term exposure to this macromolecule. Thus, HES-dependent toxicology is not expected at the dose range expected useful for HES bioconjugates.

AGEM400(HES) appears to have superior efficacy in vitro in comparison with Hematide, and competitive efficacy compared with many other ESAs. The efficacy of AGEM400 (HES) in various human cell-based assay systems was either similar to that of EPO (TF-1 and UT7/EPO cells) or similar 
to that of Aranesp (clonogenic assays on human bone marrow cells) when based on $\mathrm{ng} / \mathrm{ml}$ peptide concentration. Average EC50 values of AGEM400(HES) in the TF-1 and UT7/EPO assays were $140 \mathrm{pM}$ and $100 \mathrm{pM}$ peptide, respectively, which were lower than those reported for Hematide (900 pM and $460 \mathrm{pM}$, respectively [8]). In a recently published patent by Affymax [39] the peptide-PEG conjugate having the best efficacy (peptide 1, likely to represent $\mathrm{He}$ matide) had an EC50 of $165 \mathrm{pM}$ in murine BA/F3 cells transfected with the human EPO receptor. This is closer to the efficacy measured here for AGEM400(HES), but the cell model overexpressing EPO receptor may not be comparable with UT7/EPO or TF-1 cells. The EC50 of CNTO 530, a dimeric recombinant protein containing EMP-1 sequences, was close to $100 \mathrm{pM}$ in an UT7/EPO proliferation assay [9], which resembles the efficacy of AGEM400(HES) very well. Also, the monomeric peptide BB68 was more efficient than an analog of EMP-1, upon which the peptide sequence CNTO 530 and CNTO 528 are based [7, 9]. BB68 had an average EC50 in the TF-1 assay of $249 \mathrm{ng} / \mathrm{ml}(108 \mathrm{nM})$, while a peptide with the same sequence as EMP-1 $[5,23]$ in our laboratory showed an average EC50 of $2.8 \mu \mathrm{g} / \mathrm{ml}(1200$ $\mathrm{nM})$ in TF-1 MTS assays ( $\mathrm{n}=13$ assays; data not shown). In contrast, EMP-1 had potencies of $400 \mathrm{nM}$ or $100 \mathrm{nM}$ in proliferation assays using FDCP-1 cells expressing human recombinant EPO receptor [5, 23], which may, however, not be comparable to the assays using TF-1 cells, because the EPO receptor is probably overexpressed in transfected cells.

The efficacy of AGEM400(HES) in an assay based on murine cells (BA/F3) was much lower than in assays using human models, and about 10-fold lower than that of EPO. The sequence of BB68/AGEM400 was optimized for use on human cells and was not intended for use on murine cells or in other species. The data obtained with BA/F3 cells indicate that the efficacy of AGEM400(HES) in future in vivo experiments in mice might underestimate its efficacy in humans. Efficacy of AGEM400(HES) in clonogenic assays on cells of either human or cynomolgus origin, was similar: AGEM400(HES) induced increasing numbers of erythroid cells and colonies at concentrations between $1 \mathrm{ng} / \mathrm{ml}$ and 10 $\mathrm{ng} / \mathrm{ml}$ peptide. Translating this data to the in vivo situation, this would mean that efficacies of AGEM400(HES) measured in cynomolgus monkeys in future in vivo experiments might well be extrapolated to humans.

In future experiments, pharmacokinetics and pharmacodynamics of AGEM400(HES) in various animal models will be tested extensively. A sensitive sandwich ELISA for AGEM400(HES) is available which can detect down to 1 $\mathrm{ng} / \mathrm{ml}$ peptide in animal or human sera. Concentrations of 1 to $10 \mathrm{ng}$ AGEM400(HES) peptide/ml were active in various in vitro assays, including that monitoring erythropoiesis from human bone marrow cells, so it is likely that the levels that can be detected by sandwich ELISA are clinically relevant levels. This ELISA will thus enable the study of the pharmacokinetics of AGEM400(HES) in animal and clinical studies. These experiments will allow comparisons of the in vivo characteristics of AGEM400(HES), Hematide and CNTO 528. The latter two have already been tested extensively in vivo in preclinical $[8,9,20,21]$ and clinical $[6,7]$ settings.

The mechanism of action of AGEM400(HES) is probably similar to that of EPO, Hematide, and CNTO530 since these agents also bind to the EPO receptor with high affinity, cause phosphorylation of STAT5 in UT7/EPO cells, and stimulate survival/proliferation of cytokine-starved UT7/EPO cells $[8,9]$.

Because both AGEM400(HES), Hematide and CNTO 528 have no sequence similarity with EPO, it is very unlikely for these EPO mimetics to induce EPO-neutralizing antibodies. In humans, neutralizing anti-EPO antibodies can cause pure red cell aplasia (PRCA). It was already shown extensively that antibodies against EPO and against Hematide did not cross-react, and that Hematide was able to correct anti-EPO antibody induced anemia in rats, a rat PRCA model [40]. Titering of antibodies during the immunizations against AGEM400 peptide indicated that AGEM 400 or AGEM400(HES) might be weak immunogens: immunizations of rabbits and mice with AGEM400-KLH conjugate generated much higher titers of antibodies against KLH then against AGEM400. Still, when applied in vivo, especially in a chronic fashion, there is a chance that AGEM 400(HES) will induce anti-AGEM400 antibodies. We found no cross-reactivity between antibodies generated in rabbits and mice against AGEM400 and EPO. Even though this absence of cross-reactivity must be still be proven to be true in humans, it is not likely that anti-AGEM400 antibodies that would arise in humans treated with AGEM400, would react with endogenous EPO or to induce PRCA, In cases in which anti-EPO antibodies have already caused PRCA, AGEM400 (HES) would probably still be able to correct the anemia associated with this state.

\section{CONCLUSION}

In conclusion, AGEM400(HES) is a novel synthetic EPO mimetic that holds a promise in becoming a competitive ESA and drug candidate in the near future.

\section{AUTHOR'S CONTRIBUTIONS}

$\mathrm{AG}$ and $\mathrm{CK}$ performed research, analyzed and interpreted data, and contributed equally to this work. BB performed research. $\mathrm{UH}, \mathrm{AR}$ and $\mathrm{ME}$ provided and analysed vital reagents and contributed vital ideas. AP designed studies and wrote the paper. HGF designed studies and reviewed the paper.

\section{ABBREVIATIONS}

$\begin{array}{ll}\text { CERA } & \text { Continuous erythropoietin receptor activator } \\ \text { EMP } & =\text { Erythropoietin mimetic peptide } \\ \text { EPO } & \text { Erythropoietin } \\ \text { ESA } & =\text { Erythropoiesis stimulating agent; } \\ \text { HES } & \text { Hydroxyethyl starch } \\ \text { PEG } & \text { Polyethylene glycol } \\ \text { PRCA } & =\text { Pure red cell aplasia }\end{array}$

\section{ACKNOWLEDGEMENTS}

This work was supported in part by the German Ministry of Education and Sciences: BioChance Plus-3 grant BMBF 0315081. We are grateful to Lee Schalop for critically reviewing the manuscript. We would like to thank Prof. W. Jelkmann for kindly providing cell line UT7/EPO. 


\section{REFERENCES}

[1] Macdougall IC. Recent advances in erythropoietic agents in renal anemia. Semin Nephrol 2006; 26: 313-8.

[2] Macdougall IC, Ashenden M. Current and upcoming erythropoiesisstimulating agents, iron products, and other novel anemia medications. Adv Chronic Kidney Dis 2009; 16: 117-30.

[3] Elliot S, Pham E, Macdougall IC. Erythropoietins: a common mechanism of action. Exp Hematol 2008; 36: 1573-84.

[4] Jelkmann W. Developments in the therapeutic use of erythropoiesis stimulating agents. Br J Haematol 2008; 141: 287-97.

[5] Wrighton NC, Farrell FX, Chang R, et al. Small peptides as potent mimetics of the protein hormone erythropoietin. Science 1996; 273: 458-63.

[6] Stead RB, Lambert J, Wessels D, et al. Evaluation of the safety and pharmacodynamics of Hematide, a novel erythropoietic agent, in a phase 1, double blind, placebo-controlled, dose escalation study in healthy volunteers. Blood 2006; 108: 1830-4.

[7] Bouman-Thio E, Franson K, Miller B, et al. A phase I, single and fractionated, ascending-dose study evaluating the safety, pharmacokinetics, pharmacodynamics, and immunogenicity of an erythropoietin mimetic antibody fusion protein (CNTO 528) in healthy male subjects. J Clin Pharmacol 2008; 48: 1197-207.

[8] Fan Q, Leuther KK, Holmes CP, et al. Preclinical evaluation of Hematide, a novel erythropoiesis stimulating agent, for the treatment of anemia. Exp Hematol 2006; 34: 1303-11.

[9] Bugelski PJ, Capocasale RJ, Makropoulos D, et al. CNTO 530: Molecular pharmacology in human UT-7EPO cells and pharmacokinetics and pharmacodynamics in mice. J Biotechnol 2008; 134 : 171-80.

[10] Schellekens H. Immunological mechanisms of EPO-associated pure red cell aplasia. Best Pract Res Clin Haematol 2005; 18: 473-80.

[11] Casadevall N. What is antibody-mediated pure red cell aplasia (PRCA)? Nephrol Dial Transplant 2005; 20, (suppl 4): iv3-8.

[12] Elliot S, Egrie J, Browne J, et al. Control of rHuEPO biological activity: The role of carbohydrate. Exp Hematol 2004; 32: 1146-55.

[13] Macdougall IC. CERA (continuous erythropoietin receptor activator): A new erythropoiesis-stimulating agent for the treatment of anemia. Curr Hematol Rep 2005; 4: 436-40.

[14] Malik F, Delgado C, Knusli C, Irvine AE, Fisher D, Francis GE. Polyethylene glycol (PEG)-modified granulocyte-macrophage colony-stimulating factor (GM-CSF) with conserved biological activity. Exp Hematol 1992; 20: 1028-35.

[15] Bailon P, Palleroni A, Schaffer CA, et al. Rational design of a potent, long lasting form of interferon: a $40 \mathrm{kDa}$ branched polyethylene glycol-conjugated interferon alpha-2a for the treatment of hepatitis C. Bioconjug Chem 2001; 12: 195-202.

[16] Vicent MJ, Dieudonné L, Carbajo RJ, Pineda-Lucena A. Polymer conjugates as therapeutics: future trends, challenges and opportunities. Expert Opin Drug Deliv 2008; 5: 593-614.

[17] Bailon P, Won CY. PEG-modified biopharmaceuticals. Expert Opin Drug Deliv 2009; 6: 1-16.

[18] Webster R, Didier E, Harris P, et al. PEGylated proteins: evaluation of their safety in the absence of definitive metabolism studies. Drug Metab Dispos 2007; 35: 9-16.

[19] Yamaoka T, Tabata Y, Ikada Y. Distribution and tissue uptake of poly(ethylene glycol) with different molecular weights after intravenous administration to mice. J Pharm Sci 1994; 83: 601-6.

[20] Woodburn KW, Schatz PJ, Fong K, et al. Preclinical safety and pharmacology of Hematide, a peptidic erythropoiesis stimulating agent (ESA), in rats and monkeys. Drug Chem Toxicol 2008; 31: 229-44.

[21] Woodburn KW, Wilson SD, Fong K, et al. Chronic preclinical safety evaluation of Hematide, a pegylated peptidic erythropoiesis stimulating agent in monkeys. Haematologica 2008; 93: 1376-9.

[22] Boldt J. Modern rapidly degradable hydroxyethyl starches: current concepts. Anesth Analg 2009; 108: 1574-82.
[23] Johnson DL, Farrell FX, Barbone FB, et al. Identification of a 13 amino acid peptide mimetic of erythropoietin and description of amino acids critical for the mimetic activity of EMP1. Biochemistry 1998; 37: 3699-710.

[24] Johnson DL, Farrell FX, Barbone FB, et al. Amino-terminal dimerization of an erythropoietin mimetic peptide results in increased erythropoietic activity. Chem Biol 1997; 4: 939-50.

[25] Knorr K, Emgenbroich M, Büngerner C. Process for forming disulphide bridges. WIPO patent WO/2008/077621. 2008 July.

[26] Kitamura T, Tange T, Terasawa T, et al. Establishment and characterization of a unique human cell line that proliferates dependently on GM-CSF, IL-3, or erythropoietin. J Cell Physiol 1989; 140: 323-34.

[27] Komatsu N, Nakauchi H, Miwa A, et al. Establishment and characterization of a human leukemic cell line with megakaryocytic features: Dependency on granulocyte-macrophage colonystimulating factor, interleukin-3, or erythropoietin for growth and survival. Cancer Res 1991; 51: 341-8.

[28] Komatsu N, Yamamoto M, Fujita H, et al. Establishment and characterization of an erythropoietin-dependent subline, UT7/EPO, derived from human leukaemia cell line, UT-7. Blood 1993; 82: 456-64.

[29] Hammerling U, Kroon R, Wilhelmsen T, Sjödin L. In vitro bioassay for human erythropoietin based on proliferative stimulation of an erythroid cell line and analysis of carbohydrate-dependent microheterogeneity. J Pharm Biomed Anal 1996; 14: 1455-69.

[30] Wrighton NC, Balasubramanian P, Barbone FP, et al. Increased potency of an erythropoietin peptide mimetic through covalent dimerization. Nat Biotechnol 1997; 15: 1261-5.

[31] Vadas O, Rose K. Multivalency - a way to enhance binding avidities and bioactivity - preliminary applications to EPO. J Peptide Sci 2007; 13: 581-7.

[32] Lehmann GB, Asskali F, Boll M et al. HES 130/0.42 shows less alterations of pharmacokinetics than HES 200/0.5 when dosed repeatedly. Br J Anaesth 2007; 98: 635-44.

[33] Eisenbach C, Schönfeld AH, Vogt N, et al. Pharmacokinetics and organ storage of hydroxyethyl starch in acute hemodilution in pigs: influence of molecular weight and degree of substitution. Intensive Care Med 2007; 33: 1637-44.

[34] Leuschner J, Opitz J, Winkler A, Scharpf R, Bepperling F. Tissue storage of 14C-labelled hydroxyethyl starch (HES) 130/0.4 and HES 200/0.5 after repeated intravenous administration to rats. Drugs R D 2003; 4: 331-8.

[35] Wiedermann CJ. Hydroxyethyl starch - can the safety problem be ignored? Wien Klin Wochenschr 2004; 116: 583-94.

[36] Waitzinger J, Bepperling F, Pabst G, Opitz J, Müller M, Baron J. Pharmacokinetics and tolerability of a new hydroxyethylstarch (HES) specification [HES(130/0.4)] after single-dose infusion of $6 \%$ or $10 \%$ solutions in healthy volunteers. Clin Drug Invest 1998; 16: 151-60.

[37] Jungheinrich C, Scharpf R, Wargenau M, Bepperling F, Baron JF. The pharmacokinetics and tolerability of an intravenous infusion of the new hydroxyethylstarch $130 / 0.4(6 \%, 500 \mathrm{ml})$ in moild-tosevere renal impairment. Anesth Analg 2002; 95: 544-51.

[38] Waitzinger J, Bepperling F, Pabst G, Opitz J. Hydroxyethylstarch (HES) [130/0.4], a new HES specification: pharmacokinetics and safety after multiple infusions of $10 \%$ solution in healthy volunteers. Drugs R D 2003; 4: 149-57.

[39] Duliege AM, Stead R, Leuther K, Woodburn KW, Naso RB. Erythropoietin rceptor peptide formulations and uses. WIPO patent WO/2009/025958. 2009 Feb.

[40] Woodburn KW, Fan Q, Winslow S, et al. Hematide is immunologically distinct from erythropoietin and corrects anemia induced by antierythropoietin antibodies in a rat pure red cell aplasia model. Exp Hematol 2007; 35: 1201-8. 